\title{
Parasites of Nile tilapia (Oreochromisniloticus) from selected fish farms and Lake Koftuin central Ethio- pia
}

\author{
Marshet Adugna Mitiku ${ }^{1 *}$, Robert Konecny ${ }^{2}$, Ashalew Lakew Haile ${ }^{1}$ \\ ${ }^{1}$ National Fishery and Aquatic Life Research Center, P.O. Box 64, Sebeta Ethiopia \\ ${ }^{2}$ Environmental Agency Austria, Austria, Vienna \\ *Corresponding author email: marshetadu@gmail.com/marshet.adugna@eiar.gov.et
}

\begin{abstract}
This study was conducted from October 2016 to January 2017 at Lake Koftu, Sebeta ponds and selected private fish farms in Wonchi area, Ethiopia. The main objective was to identify the major parasites of Oreochromis niloticus to the lowest possible Taxa, thereby determine the prevalence, mean intensities and mean abundances of parasites. A total of 302 O. niloticus(101 from Lake Koftu, 127 from Sebeta pond and 72 from selected small scale fish farms) were collected and examined for the presence of parasites. The overall prevalence of all parasites in Lake Koftu, Sebeta ponds and private fish farms were found to be $100 \%, 71.0 \%$ and $82.2 \%$ respectively. There was statistically significant difference $(p<0.05)$ between the study sites in overall prevalence. Nine Taxa of parasites were identified in Lake Koftu, the Trematode Tylodelpyes spp. being the most prevalent parasite (93.1\%). In Sebeta fish ponds, 11 Taxa of parasites were recovered from $O$. niloticus with the most prevalent parasite being Trichodina (37.5\%) and four Taxa of parasites from small scale fish farms were identified and the highest prevalent parasite being with Trichodina spp (53.25\%). The study showed that fingerlings from Lake Koftu had high prevalence of parasitic infestation and hence may be source of parasites for others when used for stocking small scale fish farms requiring intervention measures such as deworming before being stocked to other farms.
\end{abstract}

Keywords: Ethiopia; Fish farms; Lake Koftu; Oreochromis niloticus; Parasites, Prevalence 


\section{Introduction}

Parasites are important components of host biology, population structure and indeed ecosystem functioning. They can be found in any fish species and within any type of aquatic and culture system (Marcogliese, 2004) They range from protozoans to metazoans including myxozoans, trematodes, cestodes, acanthocephalans, nematodes, and crustaceans (Marcogliese, 2004).The knowledge of the status of parasite diversity in the tropics is still inadequate (Dobson et al., 2008).

The Food and Agricultural Organization of the United Nations (2009) reported that to satisfy an increasing demand in freshwater fish, extensive research must include studies of their parasites for optimal production levels. The knowledge of fish parasites is of particular interest in relation not only to fish health but also to understanding ecological problems in tropical Africa(Paperna and Thurston, 1969). Fish parasites have long been recognized as serious threats of fish both in aquaculture and fisheries (Paperna and Thurston, 1969). Because of this recognition, there has been in the recent past an increasing interest and an explosion of knowledge, reports and description of new species of parasites from the African continent (Řehulkováet al., 2013). However, much of the research has been mainly concentrated in Western and Southern African countries with very little work from Eastern Africa (Gillardin et al., 2012).

Studies on fish parasites in Ethiopia are very scarce and very few research articles deal with parasites in larger water bodies including a report of fish in Lake Tana, Lake Awassa, Lake Ziway and Koka Dam (Zekarias, 2003; Tedla and Gebreeziabher, 1997; Tadesse, 1986; Yimer, 2003). This indicates a slow progress in research in fish diseases and parasites. There are also some recently published articles on fish parasites of Ethiopian water bodies such as Lake Lugo, Lake Small Abaya, Lake Ziway and Lake Awassa. (Florio et al., 2009; Bekelle and Hussien, 2015; Amare et al., 2014; Reshid et al., 2015). Koftu Lake has commercially important fish species where the National Fishery and Aquatic Life Research Center, Sebeta collects fingerlings and disseminate them for small scale fish farmers when there is demand. Most parasites can easily transfer from the wild to the cultured stocks due to direct life cycle. But in spite of the high commercial value of fish in Koftu Lake, there is no documented work for fish parasites in the Lake and no previous study on the status of parasites along the chain of fingerling stocking line from source to farmers. The main objective of this study was to investigate the most common parasites 
of $O$. niloticus (Linnaeus, 1758) and to determine the epidemiological parameters including prevalence, intensities and abundance of parasites in selected fish farms and their fingerling sources, in Ethiopia.

\section{Materials and methods}

\section{Study area}

The study was conducted in Koftu Lake, National Fishery and Aquatic Life Research Center ponds and selected private fish farms in Wonchi area, Ethiopia. Lake Koftu is located in the vicinity of Bishoftu city in Oromia Regional State and is $50 \mathrm{Km}$ west of the capital Addis Ababa. The lake is situated at an altitude of approximately 1800 masl in the North-western highlands of the country $80^{\circ} 82^{\prime} \mathrm{N}, 39^{\circ} 06^{\prime} \mathrm{E}$. There are many human activities being done at the shoreline of Lake Koftu including animal watering and washing, cloth washing. The common fish species in the Lake include O. niloticus and Tilapia zilli. The surrounding area is intensive agricultural land and farming is done to the shore of the lake. The land is not well vegetated and there is evidence of runoff in the lake which may affect the animal fauna serving as intermediate hosts for many fish parasites.

During this study, fish eating birds (final host for many helminth parasites) were observed around Lake Koftu eating fish from the lake and fish left overs. The common bird in Lake Koftu was Egyptian goose. The National Fishery and Aquatic Life Research Centre collects fingerlings from Lake Koftu to stock fish farms when there is demand. The small scale fish farms in Senkolle kebele included in this study are stocked by fingerlings from Lake Koftu.

Sebeta fish farm is located in Oromia Regional State in Sebeta city administration. It is $24 \mathrm{~km}$ far from the capital city Addis Ababa. Sebeta fish farm was established in 1977 under the ministry of agriculture now called National Fishery and Aquatic Life Research Centre under Ethiopian Institute of Agricultural Research with a mandate of conducting research related to fish and other aquatic life resources and source of fish fingerlings. When there is high demand of fingerlings and not able to produce such amount of fingerlings in hatchery, the center collects fish seeds from natural water bodies to stock small scale fish farms. The center has 32 fish rearing and experimental ponds constructed from earthen ponds, concrete ponds and geomembrane lined ponds and the farming system is semi intensive with feed supplementations. The fish species in the centre include O. niloticus (Linnaeus, 1758), Clarias garipinus 
(Bruchell, 1822) Cyprinus carpio (Linnaeus, 1758), and Tilapia zilli (Gervais, 1848) and Carasius auratus(Linnaeus, 1758). It is situated at 2200 masl and an altitude of $8^{\circ} 55^{\prime} \mathrm{N} 38^{\circ} 37^{\prime} \mathrm{E}$ covering a total area of 16 hectare. The area is characterized by a moderately warm climate with annual mean temperature of about $21^{\circ} \mathrm{C}$. The area gets annual rainfall of about $866-1200$ millimetres. The annual minimum and maximum temperature is $18^{\circ} \mathrm{C}$ to $25^{\circ} \mathrm{C}$ respectively (Sebeta Meteorology Department).

The small scale fish farms selected for this study are found in South-West Shoa zone of Oromia region, Wonchi woreda (Senkole Kebelle), Ethiopia. In the Wonchi area, farmers are organized by group and have more than 21 ponds in the district. The ponds are constructed with $15 \mathrm{~m}$ by $20 \mathrm{~m}$ for fish farming purpose with inlet and outlet for water entrance and exit. The source of water for the ponds is the river passing across the district. The source of fingerlings to stock these small scale fish farmers were from Koftu Lake. The fish species introduced include $O$. Niloticus and T. zilli. Six ponds were selected randomly and sampled for the present study. The area is characterized by mixed farming system where crop and livestock are integrated. It is located $157 \mathrm{Km}$ away from Addis Ababa at an altitude of 2,063 m above sea level with coordinates of $8^{\circ} 32^{\prime} \mathrm{N} 37^{\circ} 58^{\prime} \mathrm{E}$ (Teshome et al., 2016).

\section{Sampling design and fish sampling}

A cross sectional study was conducted from October 2016 to January 2017 to identify the most common parasites of $O$. Niloticus from the three sites. Nile tilapia is selected for this study as it is the most common commercially important fish species and commonly cultured fish in small scale fish farmers in Ethiopia. The sample size was determined based on the $5 \%$ expected prevalence and 95\% confidence limit for infinite populations (Ossiander and Wedermeyer, 1973). Accordingly, the sample size for each study site was 60 fish but for the sake of precision, the sample size for Lake Koftu, Sebeta fish ponds and selected private fish farms were increased to 101, 128 and 73 respectively. A total of 302 O. Niloticus were investigated from the three study sites. Fish were collected randomly mostly by fishing with seine nets in all the study sites. Fish were put in a fish tank with lake water and occasionally in oxygen filled polyethylene bag and transported alive to the National Fishery and Aquatic Life Research Centre, Sebeta. 


\section{Examination of fish for parasites}

The external body surface including scales, gills, fins and operculum of freshly killed fish specimens were examined for external parasites and associated pathological features. A hand lens was used for quick identification of ectoparasites on the skin and fins of the fish sample. Skin was also checked if there were capsules with metacercariae of trematodes in black dots and yellowish cysts which were sliced off the skin for further investigation. Scrapings from the fish skin were taken with a cover slip on dorsal part of the head and ventral region of the fish from head to just after the anal point and from fins. The mucus sample is then smeared onto a clean microscope slide along with a drop of pond/Lake water. The sample was then covered with a coverslip and examined under compound microscope on 100x and 400x magnification. Gills examined in situ for the presence of macro parasites and then were removed and placed in Petri dish containing normal pond water. Gill rakers were detached apart by forceps and examined under stereomicroscope for the presence of worms.

For internal examination, the fish were dissected from anus ventrally along the middle of abdomen to mouth. Then the fish was opened by cutting from anus up to the lateral line, then further along the lateral line up to operculum and the detached part was removed. Pericardial cavity, mesentery, liver, gonads, body cavity, sites behind the gills and other internal organs were checked for helminths by naked eyes and microscopically. The digestive tract was taken out together with pharynx, cleaned of adipose tissue and mesenteries; dissected along using scissors and investigated by parts. The inside part of the gut were examined by stereomicroscope and macro parasites were taken out using forceps. The eye balls were taken out using scissors and forceps. It was then crushed and examined under the stereo microscope and compound microscope. The kidneys and the liver were also examined by visual examination and under stereomicroscope after placed in a Petridish for the presence of parasites.

\section{Identification of parasites}

The identification of parasites collected was based on the distinctive body shapes and the morphological features of the collected specimen and those described in literature (Florio et al., 2009; Woo, 1995). A modified key from Paperna (1996) for identification of the major taxa of adult and larval parasites of fish was exhaustively used. The major features that were used to identify their parasites were morphological features of the parasites such as shape 
and size and predilection sites in the fish host. Taxonomic identifications were mostly limited to genus level because the fish harbours mostly larval stages of parasite and could not be distinguished to species level morphologically. The metazoan and crustacean parasites were preserved in 80\% ethanol alcohol and taken to Natural History Museum (Austria) for detail morphological identification including attachment organs, shape, and digestive organs. The specimens were placed in glycerine-ethanol for few days to remove the alcohol in them and to make it more visible under stereomicroscope (Woo, 1995).

\section{Statistical Analysis}

The collected raw data was entered in to Microsoft excel data sheets and analysed using SPSS-21 statistical software. Descriptive statistics, percentages and $95 \%$ confidence intervals were used to summarize the proportion of infested fish. Statistical significance was set at $p<0.05$. Prevalence, intensity and abundance were analysed by using the calculations formulated by Bush et al (1997).

Prevalence (p) is the proportion of the number of infected hosts over the number of hosts examined (Bush et al., 1997).

Mean Intensity (Mi) is the mean number of parasites of one taxonomic group found in an infected host (Bush et al., 1997).

Mean abundance (Ma) is the mean number of parasites of one taxonomic group found on hosts that were examined (Bush et al., 1997).

\section{Results}

In this study, a total of $302 \mathrm{O}$. Niloticus fish caught randomly from the study sites were examined for the presence of parasites from October 2016 to February 2017. Different genera of fish parasites both from internal organs and external body surfaces of $\mathrm{O}$. Niloticus were identified. Out of the $302 \mathrm{O}$. Niloticus examined in the three study areas, 251 (83.4\%) of them were infested with single or multiple parasites belonging to different genera. The fish from Lake Koftu showed $100 \%$ prevalence followed by private fish farms with a prevalence of $82.2 \%$. Nile tilapia from the National Fishery and Aquatic Life Research Centre, Sebeta ponds have relatively lower prevalence than others (71.1\%) (Table 1). 
Table 1. Overall prevalence of parasites of O. niloticus at Lake Koftu, Sebeta ponds and private farms $(n=302)$

\begin{tabular}{lccc}
\hline Study site & Sampled (n) & Number infected & Prevalence (\%) \\
\hline Koftu Lake & 101 & 101 & 100 \\
Sebeta ponds & 128 & 91 & 71.1 \\
Private farms & 73 & 60 & 82.2 \\
Total & 302 & 252 & 83.4 \\
\hline
\end{tabular}

The most prevalent parasites species in all the three study sites were the external parasites protozoan Trichodina spp. from skin and gills and the monogenetic trematode Cichlidogyrus spp. from the gills with a prevalence of $52.96 \%$ and $52.63 \%$ respectively followed by the digenean trematodeTylodelphys spp. from the eye of the fish (Table 2).

Table 2. Total prevalence (P), mean intensities (MI), mean abundance (MA) of O. Niloticus parasites at Lake Koftu, Sebeta ponds and private farms $(\mathrm{n}=302)$

\begin{tabular}{lllccc}
\hline Parasite Taxa & Location Host & $\begin{array}{l}\text { Developmental } \\
\text { stage }\end{array}$ & P (\%) & MI & MA \\
\hline Ectoparasites & & & & & \\
Trichodinaspp. & Gills & Adult & 52.9 & - & - \\
Cichlidogyrusspp. & Gills & Adult & 52.6 & 10.4 & 5.5 \\
Dolops & Skin & Adult & 3.3 & 0.2 & 0.01 \\
Endo parasites & & & & & \\
Clinostomumspp. & Brachial cavity & Larvae & 20.1 & 3.51 & 0.7 \\
Euclinostomumspp. & Gills/Kidney & Larvae & 16.8 & 5.8 & 0.9 \\
Tylodelphysspp. & Gill cavity & Larvae & 36.5 & 7.3 & 2.7 \\
Blackspotmetacercariae & Skin/gills & Larvae & 19.1 & - & - \\
Cestoda larvae & Gut wall & Larvae & 9.9 & - & - \\
Contracaecumspp. & Pericardial & Larvae & 25.3 & 5.5 & 1.4 \\
& cavity & & & & \\
Unidentified Nematode & Body cavity & Larvae & 0.99 & 5.0 & 0.1 \\
Acanthogyrustilapiae & Intestine & Adult & 5.3 & 7.0 & 0.4 \\
\hline - Data not available & & & & &
\end{tabular}

All 101 O. niloticus sampled and investigated for the presence of parasites from Lake Koftu were found to be infested with single or multiple parasites 
and the overall prevalence was $100 \%$. Nine genera of parasites were identified in Lake Koftu and their prevalence, mean intensity and mean abundance were determined (Table 3). Accordingly, the most dominant parasite in this Lake was the digenean trematode Tylodelpys spp. with a prevalence of $93.2 \%$ and mean intensity of 8.4 per infected fish. Trichodina spp. from the skin and gills and Cichlidogyrus spp. from the gills were the other most common external parasites with prevalence of $70.6 \%$ and $77.5 \%$. Euclinostomum spp. from the kidney was the least prevalent parasite (0.98\%) (Table 3).

Table 3. Prevalence (P), Mean intensities (MI), Mean abundance (MA) of $O$. Niloticus parasites in Koftu Lake (n=101).

\begin{tabular}{lllccc}
\hline Parasite species & Location Host & $\begin{array}{l}\text { Developmental } \\
\text { stage }\end{array}$ & P (\%) & MI & MA \\
\hline $\begin{array}{l}\text { Ecto-parasites } \\
\text { Trichodinaspp. }\end{array}$ & Skin and Gills & Adult & 70.6 & - & - \\
Cichlidogyrus spp. & Gills & Adult & 77.5 & 12.3 & 9.7 \\
$\begin{array}{l}\text { Endo-parasites } \\
\text { Clinostomumspp. }\end{array}$ & Brachial cavity & Larvae & 51 & 3.4 & 1.7 \\
Euclinostomumspp. & Gills/kidney & Larvae & 1 & 5.0 & 0.1 \\
Tylodelphysspp. & Gill cavity & Larvae & 93.1 & 8.4 & 7.8 \\
Blackspotmetacercariae & Skin/gills & Larvae & 27.5 & - & - \\
Cestode larvae & Gut wall & Larvae & 20.6 & - & - \\
Contracaecumspp. & Pericardial cavity & Larvae & 53.9 & 5.3 & 2.8 \\
Unidentified nematode & Body cavity & Larvae & 1.9 & 7.5 & 0.2 \\
\hline -Unavailable data & & & & &
\end{tabular}

In Sebeta ponds, 128 O. niloticus were sampled and out of them 91(71.9\%) were infested with one or multiple parasites. Eleven genera of both external and internal parasites were identified in this study site. Trichodina spp.from skin and gills and Cichlidogyrus spp. from gills were the most prevalent external parasites in Sebeta ponds with prevalence of 37.50 and $33.59 \%$ respectively (Table 4). 
Table 4. Prevalence (P), Mean intensities (MI), Mean abundance (MA) of $O$. niloticus parasites Sebeta ponds $(\mathrm{n}=128)$.

\begin{tabular}{|c|c|c|c|c|c|}
\hline Parasite Taxa & Location Host & $\begin{array}{l}\text { Developmental } \\
\text { Stage }\end{array}$ & P (\%) & MI & MA \\
\hline \multicolumn{6}{|l|}{ Eecto-parasites } \\
\hline Trichodina spp. & Gills & Adult & 37.5 & & \\
\hline Cichlidogyrus spp. & Gills & Adult & 33.6 & 13.0 & 4.4 \\
\hline Dolopsspp. & Skin & Adult & 7.8 & 0.2 & 0.0 \\
\hline \multicolumn{6}{|l|}{ Endo-parasites } \\
\hline Clinostomum spp. & Brachial Cavity & Larvae & 7.1 & 4.4 & 0.3 \\
\hline Euclinostomum spp. & Gills/kidney & Larvae & 9.4 & 5.6 & 0.5 \\
\hline Tylodelphys sp. & Gill cavity & Larvae & 12.5 & 0.8 & 0.1 \\
\hline Blackspotmetacercariae & Skin/gills & Larvae & 23.4 & - & - \\
\hline Cestod larvae & Gut wall & Larvae & 7.0 & - & - \\
\hline Contracaecum spp. & Pericardial cavity & Larvae & 17.2 & 5.9 & 1.0 \\
\hline unidentified nematode & Body cavity & Larvae & 0.8 & - & - \\
\hline Acanthogyrustilapiae & Intestine & Adult & 11.7 & 7.3 & 0.9 \\
\hline
\end{tabular}

Out of the 73 O. niloticus sampled in private farms, 60 (82.19\%) of them were found harbouring single or multiple parasitic infestation. Trichodina spp., Cichlidogyrus spp, Euclinostomum spp, and Acanthocephala spp were the four parasitic genera encountered in private fish farms. Trichodina spp. and Euclinostomum spp. were the most common external and internal parasites respectively (Table 5). This study site showed the lowest number of parasite taxa among the three study sites.

Table 5. Prevalence (P), Mean intensities (MI) and, Mean abundance (MA) of O. niloticus parasites in selected private fish farms $(n=73)$.

\begin{tabular}{llllll}
\hline Parasite Taxa & Predilection site & $\begin{array}{l}\text { Developmental } \\
\text { stage }\end{array}$ & P (\%) & MI & MA \\
\hline $\begin{array}{l}\text { Ecto-parasites } \\
\text { Trichodina spp. }\end{array}$ & Gills & Adult & 53.25 & - & - \\
$\begin{array}{l}\text { Cichlidogyrus spp. } \\
\text { Endo-parasites }\end{array}$ & Gills & Adult & 49.35 & 2.84 & 1.40 \\
Euclinostomum spp. & Gills/Kidney & Larvae & 49.35 & 5.92 & 2.92
\end{tabular}

Ethiop. Vet. J., 2018, 22 (2), 65-80 
Mitiku et al.,

\begin{tabular}{llllll}
\hline Acanthogyrus tilpiae & Intestine & Adult & 1.30 & 2.00 & 0.03 \\
\hline Unavailable data & & & & & \\
\hline
\end{tabular}

\section{Discussion}

The present study indicated that the protozoan parasite Trichodina spp. is found in the three study sites. Previous reports showed that Trichodina spp. was recorded on fish in Kenya, Uganda and Ethiopia in cages, ponds and natural water bodies (Florio et al., 2009). The prevalence showed lower values in natural water bodies and higher in cultured fisheries. For example in Uganda, a comparative study conducted in ponds, cages and wild $O$. niloticus fish showed a prevalence of $34.6 \%, 22.2 \%$ and $1.8 \%$ respectively (Florio et al., 2009). Tadesse, (2009) also reported higher prevalence of Trichodina spp. in cultured systems in Yemlo and Wonji ponds with a prevalence of 56.7 and $46.7 \%$ respectively, but lower prevalence in natural water bodies of Lake Awassa and Lake Babogaya with prevalence of $10 \%$ and $14.4 \%$. In contrast, the present investigation revealed different results than the above mentioned studies. The prevalence of Trichodina spp in Lake Koftu (70.6\%) which is a natural water body is much higher than from cultured fish in Sebeta ponds (37.6\%) and private fish farms (53.3\%). The regular monitoring of water quality by changing water at Sebeta ponds and fish farms as management practice may probably be the reason for the low infestation of Trichodina spp. in cultured Nile Tilapia. The human activities in and around Lake Koftu might cause deterioration of the water quality due to high organic matter load which favors the proliferation of Trichodina spp. In fish farms, Trichodina spp. is indicator of poor water quality and continuous water flow can prevent its build up in fish farms and low flowing water bodies. Further studies should be done considering biotic parameters such as fish density, abundance and abiotic factors including nutrients and other water quality parameters. Most protozoan parasites are ubiquitous in aquatic systems and can cause great loss in fish farms by parasite induced host mortality. This might be supported by poor water quality and presence of external damage on fish body which lead to stress and favour the multiplication of the parasite on fish (Paperna, 1996).

Among the monogeneans, Cichlidogyrus spp. was observed from all the three study sites in gills of $O$. niloticus. It is an external monogenetic trematode common in African water bodies reported from Uganda and Ethiopia (Florio et al., 2009). High prevalence of Cichlidogyrus spp. $77.5 \%$ was found in Lake Koftu and the lowest being in Sebeta ponds with prevalence of $33.6 \%$. This agrees 
with reports from Uganda where the highest prevalence was found in wild fish with prevalence of $63.4 \%$ compared to cultured fish which is $31.7 \%$ (Florio et al., 2009). This result also contradicts with the idea of Martines et al (2015) who explained that external parasites are more successful in fish farms where they spread easily to multiple hosts because of the overcrowding. They have the ability to reproduce faster and transmit from fish to fish in aquaculture. Low water exchange and poor bottom hygiene as well as stocking density are the main risk factors favouring spread of infestation and may represent a further conditioning factor leading to heavy gill infestation in farmed fish (Florio et al., 2009). The higher prevalence in Lake Koftu and lower prevalence in Sebeta ponds might probably be due to the fact that water in Sebeta ponds is regularly regulated and there is continuous discharge of water to the ponds. The agricultural activity around the shore of Lake Koftu may also contributed to the water quality deterioration and high reproduction of the parasites.

The digenean trematode Clinostomum spp.was one of the most common parasites identified in Lake Koftu and Sebeta ponds. This parasite species was also identified in many water bodies in Ethiopia including Lake Tana (Yimer, 2003), Yemlo and Wonji pond, lake Babogaya and Lake Awassa (Tadesse, 2009), Lake Lugo (Amare et al., 2014), Koka reservoir (Gulilat et al., 2013), Small Abaya Lake (Reshid et al., 2015) and Lake Ziway (Bekelle and Hussien, 2015).

The prevalence of Clinostomum spp. in Lake Koftu was 51\% and mean intensity was 3.4. The results are similar to reports of Clinostomum spp. From $O$. niloticus at Lake Awassa with a prevalence of $50 \%$, but the mean intensity was higher in Lake Awassa with 7 worms per fish. This could be attributed to the size of the fish sampled for the study. The size of the fish sampled in this study was smaller ranging from $6.5 \mathrm{~cm}$ to $18 \mathrm{~cm}$ in Lake Koftu. Smaller fish harbor lower numbers of parasites than bigger fish as there is a longer duration of exposure to parasitic agents in the environment which increases the chance of acquiring more parasites. Small fish also provide smaller surface area for the parasite availability on the host than larger fish (Amare et al., 2014). It's prevalence in Lake Koftu was higher than reported in Lake Lugo with a prevalence of $33.8 \%$ (Amare et al., 2014), Koka reservoir with prevalence of $27.4 \%$ (Gulilat et al., 2013) and Small Abaya Lake with a prevalence of $18.8 \%$ (Reshid et al., 2015). The prevalence in Sebeta ponds was 7\% with 4.4 worms per infested fish which is lower than Yemlo pond with a prevalence of $23.3 \%$ and Wonji cages with a prevalence of $20 \%$ (Tadesse, 2009; Florio et al., 2009). This variation in prevalence of Clinostomum spp. could be due to the fact that, it has an indirect 
life cycle with snails as first intermediate and fish eating birds as final host and the fish itself as the second intermediate host. Therefore, lower and higher abundance of the snail intermediate hosts and the fish eating birds as final host in the different study sites might play a contributing role in the variation of the prevalence.

In this study, Euclinostomum spp. was found primarily in the kidney but also recorded from the gonads and brachial cavity of O. niloticus. Euclinostomum spp. was identified in Lake Koftu, Sebeta ponds and selected private fish farms in Wonchi area. It was also recorded in Ethiopia and Kenya from BOMOSA cage fish (Florio et al., 2009) like Machakose and Sagana farms (Otachi, 2009) and Wonji cages and Awassa Lake (Tadesse, 2009). The presence of Euclinostomum spp. was highest in selected private fish farm with a prevalence of $49.4 \%$ and a mean intensity of 5.9. This prevalence is much higher than reported by Florio et al (2009) in Kenya Mackakose and Sagana BOMOSA cages which was $1.4 \%$, and BOMOSA cages in Ethiopia with a prevalence of $9.3 \%$. It is also higher than report from Lake Awassa and Wonji Cages with prevalence of $10 \%$ and $6.7 \%$ respectively. It shows also higher values of mean intensity with 5.9 worms per fish than Lake Awassa and Wonji cages where mean intensity was 1 (Tadesse, 2009).

The digenean Tylodelphys spp.was found in O. niloticus of Lake Koftu and Sebeta ponds in the present study but not in private farms. This parasite was reported in Kenya from fish of Machakose and Sagana fish farms (Otachi, 2009). In Ethiopia, it was reported in Wonji ponds, Lake Babogaya and Lake Awassa (Tadesse, 2009). It was the most dominant parasite in Kofu Lake with a prevalence of $93.2 \%$ and mean intensity of 8.4 worms per fish. This result is much higher than the prevalence recorded in Lake Babogaya, Wonji pond, and Lake Awassa in Ethiopia with prevalence of 2.8\%, 6.6\% and 6.7\% respectively (Tadesse, 2009). Florio et al (2009) also reported 52\% prevalence of Tylodelphys spp. in ponds and 50\% in wild fish in Kenyan water bodies which is lower than the present study. The higher prevalence of Tylodelphys spp. in Lake Koftu could be associated to higher seasonal peaks of the intermediate hosts in the lake and availability of high numbers of fish eating birds which increase the abundance of the parasites.

In this study, the nematode Contracaecum spp. was found in Koftu Lake and Sebeta ponds but not encountered in selected fish farms. It was reported in many African countries including Nigeria, Uganda, Kenya (Otachi, 2014). It 
was also recorded from many Ethiopian water bodies such as Koka reservoir, Yemlo ponds, Lake Babogaya, Lake Tana and Lake Small Abaya (Yimer and Eniyewu, 2003; Tadese, 2009; Florio et al., 2009; Gulilat et al., 2013; Reshid et al, 2014). The prevalence of Contracaecum spp. in Koftu Lake was 53.9\% with mean intensity of 5.3 and a prevalence of 17.2 with mean intensity of 5.9 worms per infested fish in Sebeta ponds. There was no record of this parasite in selected private fish farms. There is a significant difference $(p<0.05)$ in prevalence of this parasite in the different study sites. This might be attributed to differences in the diversity and availability of invertebrate intermediate hosts and fish eating birds to complete its developmental cycle.

In this study, Acanthogyrus tilapiae was recorded in Sebeta ponds and selected private fish farms in Wonchi area. This could be the first report of the parasite in Ethiopian water bodies. It was recorded from some of African countries such as Nigeria, Uganda, Kenya and Malawi (Amin and Hendrix, 1999; Otachi, 2009; Florio et al., 2009; Uhuo et al., 2014). The prevalence of A. tilapiae in Sebeta ponds is higher than the prevalence in private fish farms. The results from Sebeta ponds showed almost similar values of prevalence compared to $10.2 \%$ prevalence of wild tilapia in Uganda and pond fish (7.9\%) and wild tilapia (7.1\%) from Kenya (Florio et al., 2009), respectively. The mean number of A. tilapiae per fish is 7.3 which was much higher than the one reported by Florio et al (2009) in Uganda and Kenya which was1.6 in Ugandan wild tilapia and 2.1 and 2.9 in Kenyan caged and pond tilapia respectively. This difference in mean intensity of the parasites may be explained by the differences in the water quality where the fish is living and the immune status of the fish in each study sites. It may also be associated with abundance of the crustacean, which serves as intermediate hosts for acanthocephalans.

Among the crustaceans, Dolops spp. was recovered from $O$. niloticus of Sebeta ponds with a prevalence of $7.8 \%$ and mean intensity of 1 . It was reported in Lake Tana, Lake Awassa, and Lake Babogaya in Ethiopia. A report done by Tadesse(2009) indicated that Dolopsranarum was recorded from African catfish with intensities of 85 parasites per host in Lake Awassa. This species of crustaceans were also reported from Lake Tana on African catfish (Yimer, 2003). They were also observed on Nile tilapia from Wonji out of cages, Lakes Babogaya and Awassa but with lower prevalence and intensities ranging from 3 to $8.6 \%$ (Florio et al., 2009). 


\section{Conclusion}

A total of 11 genera of external and internal parasites were found in O. niloticus in three study sites. All O. Niloticus sampled from Lake Koftu harboured single or multiple parasites. External parasites such as Trichodina spp. and Cichlidogyrus spp. were found on fish in all the three study sites but the Digenea Tylodelphys spp. was the most dominant parasite in Lake Koftu as there were many fish eating birds around the lake. Therefore, there is a need to design control strategies especially when fingerlings from the natural water bodies are used for stocking in other water bodies or intensive and small scale fish farms to prevent transmission of fish parasites to the culture system. Further studies should be conducted to identify parasites to species level by molecular techniques and parasite genomics of culture fish species. Biotic factors like stocking density and abiotic factors like water chemistry and water quality which can influence the abundance of parasites should also be taken into consideration in surveys of fish parasites.

\section{Acknowledgements}

Authors would like to thank and appreciate National Fishery and Aquatic Life Research Centre, Royal Government of The Netherlands through UNESCOIHE and Austrian Academy of Science through IPGL for their fund in collaboration.

\section{Conflict of interest}

The authors declare that there is no conflict of interest.

\section{References}

Adugna, M., R., M., Redda, Y. T., Awol, N. and Teklu, A., 2015. A study of Clinostomum (trematode) and Contracaecum (nematode) parasites affecting Oreochromisniloticus in Small Abaya Lake, Silite Zone, Ethiopia. Dev., J. Aquac. Res. Dev., 6,316. doi:10.4172/2155-9546.1000316

Amare, A., Alemayehu, A. and Aylate A., 2014. Prevalence of Internal Parasitic Helminthes Infected Oreochromisniloticus(Nile Tilapia), Clariasgariepinus(African Catfish) and Cyprinuscarpio(Common Carp) in Lake Lugo (Hayke), Northeast Ethiopia. J. Aquac. Res. Dev. 5, 233 doi: 10.4172/2155-9546.1000233. 
Amin, O. M. and Hendrix, S. S., 1999. Acanthocephala of cichlids (Pisces) in Lake Malawi, Africa, with a description of Acanthogyrus (Acanthosentis) malawiensis sp. $\mathrm{n}$. (Quadrigyridae) from Labeocylindricus Peters, 1852 (Cyprinidae). Compara. Parasitol. $66,47-55$.

Bekele, J. and Hussien, D., 2015. Prevalence of internal parasites of O. niloticus and C. gariepinus fish species in Lake Ziway, Ethiopia. J. Aquac Res. and Dev., 6(2). 6,308. doi: 10.4172/2155-9546.1000308

Bush, A. O., Lafferty, K. D., Lotz, J. M. and Shostak, A. W., 1997. Parasitology meets ecology on its own terms: Margolis et al. revisited. The J. parasitol, 575-583.

Dobson, A., Lafferty, K. D., Kuris, A. M., Hechinger, R. F. and Jetz, W., 2008. Homage to Linnaeus: How many parasites? How many hosts? Proce. National Acad. Sci., 105, 11482-11489.

Florio, D., Gustinelli, A., Caffara, M., Turci, F., Quaglio, F., Konecny, R. and Matolla, G. K., 2009. Veterinary and public health aspects in tilapia (Oreochromisniloticus) aquaculture in Kenya, Uganda and Ethiopia. Ittiopatologia, 6, 51-93.

Gillardin, C., Vanhove, M. P. M., Pariselle, A., Huyse, T. and Volckaert, F. A. M., 2012. Ancyrocephalidae (Monogenea) of Lake Tanganyika: II: description of the first Cichlidogyrus spp. parasites from Tropheini fish hosts (Teleostei, Cichlidae). Parasitol. Res., 110, 305-313.

Gulelat, Y., Yimer, E., Asmare, K. and Bekele, J., 2013. Study on parasitic helminths infecting three fish species from Koka reservoir, Ethiopia. SINET: Ethio. J. Sci., 36(2), 73-80.

Marcogliese, D. J., 2004. Parasites: small players with crucial roles in the ecological theatre. Ecohealth 1, 151-164.

Martins, M. L., Azevedo, T. M., Ghiraldelli, L. and Bernardi, N., 2010. Can the parasitic fauna on Nile tilapias be affected by different production systems? Anais da Academia Brasileira de Ciências, 82(2), 493-500.

Ossiander, F. and G. Wedermeyer. 1973. Computer program for sample size required to determine disease incidence in fish populations. J. Fisheries Res. Board of Canada 30, 1383-1384.

Otachi, E. O., Magana, A. E., Jirsa, F. and Fellner-Frank, C., 2014. Parasites of commercially important fish from Lake Naivasha, Rift Valley, Kenya. Parasitol. Res., 113(3), 1057-1067.

Paperna, I. and Thurston, J. P., 1969. Report on Ectoparasitic Infections of Fresh Water Fish in Africa. Bull. Anim. Hlth. Prod. Afr., 69 (7-8), 1197-1206 
Paperna, I., 1996. Parasites, infections and diseases of fishes in Africa: An update. CIFA Technical paperNo.31, FAO publication, Rome, Italy.

Řehulková, E., Mendlová, M. and Šimková, A., 2013. Two new species of Cichlidogyrus (Monogenea: Dactylogyridae) parasitizing the gills of African cichlid fishes (Perciformes) from Senegal: morphometric and molecular characterization. Parasitol. Res., 112(4), 1399-1410.

Tadesse, A. 1986. Parasites of fish from Lake Awasa and Chamo, DVM.Thesis, Faculty of Veterinary Medicine, Addis Abeba University, DebreZeit, Ethiopia. Pp. 13-15.

Tadesse, B., 2009. Prevalence and abundance of fish parasites in BOMOSA cage systems and Lakes Babogaya and Awasse. Ethopia. Thesis (M. Sc.): UNESCO-IHE, The Neverlands.

Tedla S. and Gebreegziabher T., 1997. Observation on parasites of Tilapia nilotica and Clariasmossaambicusat Lake Awassa, Ethiop. J. Agri. Sci.,2, 126-130.

Teshome, H., Teshome, K. and Dagne, A., 2016. Potentials and challenges of smallholder fish farming in Ethiopia: The case of South West and West Showa Zones, Oromiya, Ethiopia: J. Sci. Sustainable Dev., 4(1), 53-60

Woo, P.T.K., 1995. Fish disease and disorder: Protozoan and Metazoan Infection volume1. CABI international, walling ford, UK.Pp. 45- 46.

Yimer, E. and Eniyewu, M., 2003. Parasites of fish at Lake Tana, Ethiopia. Faculty of science, Addis Ababa University, Ethiopia. SINET: Ethiop. J. Sci., 26(1), 31-36.

Yimer, E., 2003. Preliminary survey of parasites and bacterial pathogens of fish at Lake Ziway. SINET: Ethiop. J. Sci., 23, 25-33.

Zekarias T., 2003. Study on parasites of fish at Lake Awasa, DVM thesis, Addis Ababa University, Faculty of Veterinary Medicine. DebreZeit, Ethiopia. 